\title{
Effect of Different Herbicidal Treatments on Soil Microflora in Maize - Greengram Crop Sequence
}

\author{
A. Subba Ramireddy*, A.S. Rao, G. Subba Rao, T.C.M. Naidu, \\ A. Lalitha Kumari and N. Trimurthulu \\ Department of Agronomy, Acharya N. G. Ranga Agricultural University, Guntur, \\ Andhra Pradesh, India \\ *Corresponding author
}

\section{A B S T R A C T}

\section{Keywords \\ Herbicides, Total bacteria, Actinomycetes, Total fungi \\ Article Info \\ Accepted: xx October 2018 Available Online: xx November 2018}

\begin{abstract}
The highest total bacteria, actinomycetes and fungi count was recorded in atrazine @ 1.25 $\mathrm{kg}$ ai ha ${ }^{-1}$ as pre-emergence $f b$ topramezone @ $25 \mathrm{~g}$ ai ha ${ }^{-1}$ at 20 DAS as post-emergence (T6) which was superior over all other treatments during both the years of study and the lowest was recorded in weedy check. The soil micro flora was not influenced by any herbicides applied but the microbial soil inoculants applied to maize crop influenced the nutrient availability, increase in total bacteria, fungi and actinomycetes in the soil, which ultimately reflected in the yield attributing characters and yield and it confirmed that recommended dose of fertilizers can be reduced by 25 per cent by applying microbial inoculants to maize.
\end{abstract}

\section{Introduction}

Maize (Zea mays L.) is one of the most important crops among the cereals in the world agricultural economy both as food and fodder crop and is regarded as "queen of cereals". Under changing climatic scenario improving and maintaining soil health for sustaining agriculture production is of utmost importance for India's food and nutritional security. Legume-based cropping systems could help to increase crop productivity and soil organic matter levels, thereby enhancing soil quality, as well as having the additional benefit of sequestering atmospheric carbon. In Andhra Pradesh, rabi maize followed by greengram crop sequence is promising for reaping high returns by farmers but many reasons are responsible for the lower yields of maize. Among the several factors, the most dominant factor responsible for the lower yields of maize are weeds, which competes with crop for nutrients, water, sunlight and space.

Wide spacing, intensive use of inputs and initial slow growth of maize are some of the factors responsible for increased weed growth. Weeds can suppress crop growth and yield by effectively competing with crop for environmental resources like water, light, nutrients and production of allelopathic compounds. The extent of reduction in grain yield of maize has been reported to be in the 
range of 33 to 50 per cent depending on type of weed species in standing crop (Hawaldar and Agasimani, 2012). At the earlier times, since no synthetic chemicals were known, weed control was achieved by some methods such as hand weeding, crop rotation, polyculture and other management practices that were low input but sustainable. With the discovery of synthetic herbicides in the early 1930s, there was a shift in control methods towards high input and target-oriented ones. Now labour component in agriculture is becoming scarce, not available at time and cost prohibitive. Use of herbicides to manage weeds forms an excellent alternative to manual weeding. In India, till date only preemergence application of atrazine / pendimethalin has been widely recommended for the control of weeds in maize. There is a need of post-emergence herbicide usage for management of weeds which occur at 15-25 days of crop and offer severe competition for growth resources, thereby lowering the productivity of maize. Hence, it is proposed to test the new post emergence herbicides without residual effect in maize has greater field applicability. In most farming systems, competition for nitrogen $(\mathrm{N})$ is the most important factor than that of for all other nutrients, plant response to $\mathrm{N}$ fertilizer is widely observed and the manipulation of soil $\mathrm{N}$ supply offers the most promise in the short term as a means by which crop-weed competitive outcomes can be influenced. It is well known that large fraction of the millions of tonnes of nutrients added to soils every year are not taken up by crop plants, as up to $50 \%$ of added nitrogen and 0.4 to $90 \%$ of added phosphorus going waste from crop fields (Simpson et al., 2011). This situation can be alleviated by employing microbial inoculants, which are beneficial to soil and rhizobacteria capable of promoting plant growth while reducing fertilizer inputs up to $50 \%$ without any yield loss compared to fully fertilized controls (Hayat et al., 2010). These inoculants provide several possible strategies to enhance plant growth, such as the solubilization and recycling of nutrients, the production of plant growth hormones, nitrogen fixation, the induction of enhanced plant defenses and the production of antibiotics, soil detoxification and others. Microbial numbers and enzyme activity are usually used as indicators of soil fertility and health (Zang et al., 2010). Hence the present study is conducted to know the effect of different herbicidal treatments on soil microflora in maize - greengram crop sequence at RARS, Lam, Guntur, Andhra Pradesh.

\section{Materials and Methods}

The experiment was spread into two seasons in each year conducted as a sequence during rabi and summer seasons of the years 2013-14 and 2014-15 which are presented in the following sub heads.

\section{Rabi Season}

Crop: Maize

Spacing: $60 \mathrm{~cm}$ x $20 \mathrm{~cm}$

Design: Split-plot

Replications: Three

Fertilizers: As per treatments

Herbicides: As per treatments

In case of pre and post-emergence herbicide treatments, the required quantity of herbicide formulation was dissolved in water, using a spray volume of $500 \mathrm{l} \mathrm{ha}{ }^{-1}$ and sprayed uniformly using a knapsack sprayer fitted with flat fan nozzle after sowing of maize as per schedule. Weeds were not removed throughout the crop growth period in unweeded control/weedy check $\left(\mathrm{T}_{1}\right)$.

The enumeration of total bacteria, fungi, actinomycetes in the soil samples collected from the experimental plots before sowing and after harvest of maize and greengram was 
estimated by following the standard dilution plate count technique by pour plate technique Nutrient agar (NA) for bacteria, Martin's rose bengal with streptomycin sulphate agar (MRBA) for fungi, Ashby's agar for actinomycetes were used for enumeration. The petri plates were incubated after plating at 30 ${ }^{0} \mathrm{C}$ for two to four days and population was counted and expressed as number of cells per gram on dry weight basis for bacteria, actinomycetes and $\mathrm{cfu} \mathrm{g}^{-1}$ of soil for fungi The microbial populations i.e., fungi, bacteria and actinomycetes per gram of soil on dry weight basis were estimated by the procedure developed by Allen (1957).

\section{Results and Discussion}

Total Bacteria (CFU/g soil) count after harvest of maize and before sowing of greengram

Weed management and nutrient management practices significantly influenced the total bacteria countafter harvest of maize and before sowing of greengram during the both the years of investigation (Table 1). The highest total bacteria count was recorded in atrazine @ $1.25 \mathrm{~kg}$ ai ha ${ }^{-1}$ as pre-emergence fbtopramezone@25 $\mathrm{g}_{\text {ai ha }}{ }^{-1}$ at $20 \mathrm{DAS}$ as post-emergence (T6) which was superior over all other treatments during both the years of study and the lowest was recorded in weedy check.

With regard to total bacteria count weed management practices differ among themselves. This could be due to the combined synergistic effect of atranize and topramezone in enhancing the total bacterial community in the soil when compared to the other herbicidal combinations and it was fbtopramezone @ 25 $\mathrm{g}$ ai ha ${ }^{-1}$ at 20 DAS as post-emergence (T4), where the presence of sulphur compound might have influenced the proliferation of total bacterial numbers in the soil. These results are in close to the findings of Shannon et al., (2002). With regard to nutrient management practices, the highest total bacteria count was recorded in $\mathrm{F} 2(75 \% \mathrm{RDF}+\mathrm{MI})$ which was significantly superior over F1 (50\% RDF+MI) and F3 (100\% RDF) during the both the years of investigation. The application of $75 \% \mathrm{RDF}$ might have acted as optimum dose for the multiplication of the total bacterial numbers when compared to $100 \% \mathrm{RDF}$ and $50 \% \mathrm{RDF}$.

Total actinomycetes (CFU/g of soil) count after harvest of maize and before sowing of greengram

Weed management and nutrient management practices significantly influenced the total actinomycetes count after harvest of maize and before the sowing of greengram during the both the years of investigation (Table 2). The highest total actinomycetes count was recorded in atrazine @ $1.25 \mathrm{~kg}$ ai ha ${ }^{-1}$ as preemergence fbtopramezone @ $25 \mathrm{~g}_{\text {ai ha }}{ }^{-1}$ at 20 DAS as post-emergence (T6) which was onpar with T4, T7 and T8 treatments during both the years of study. The lowest was recorded in weedy check (T1). With regard to total bacteria count weed management practices differ among themselves. This could be due to the less effect of herbicidal specificity on the actinomycetes group after the prolonged period after application in the soil. These findings are same as reported by Thrimurthulu et al., (2015). With regard to nutrient management practices, the highest total actinomycetes count was recorded in F2 (75\% $\mathrm{RDF}+\mathrm{MI})$ which was on par with $\mathrm{F} 1 \quad(50 \%$ $\mathrm{RDF}+\mathrm{MI})$ and these treatments were significantly superior over F3 (100\% RDF) during the both the years of investigation. May be due to the fact that the application of $75 \% \mathrm{RDF}$ or $50 \% \mathrm{RDF}$ along with bio consortium might have acted as optimum dose for the multiplication of the total actinomycetes numbers when compared to $100 \%$ RDF. 


\section{Details of treatments}

Main Plots

Weed management Practices

\begin{tabular}{|c|c|}
\hline T1- Weedy check & \multirow{13}{*}{$\begin{array}{r}\text { Greengram was grown as a } \\
\text { sequence crop }\end{array}$} \\
\hline T2-Atrazine@1.25 kg a.i ha ${ }^{-1}$ as pre-emergence & \\
\hline T3-Pendimethalin @ $0.75 \mathrm{~kg} \mathrm{a.i} \mathrm{ha}^{-1}$ as pre-emergence & \\
\hline T4- Topramezone @ $25 \mathrm{~g}_{\text {a.i }} \mathrm{ha}^{-1}$ at 20 DAS as post-emergence & \\
\hline T5- Tembotrione@110 g a.i ha ${ }^{-1}$ at 20 DAS as post-emergence & \\
\hline T6- T2 fb T4 & \\
\hline T7- T2 fb T5 & \\
\hline T8- T3 flo T4 & \\
\hline T9- T3 fb T5 & \\
\hline $\begin{array}{l}\text { Sub-Plots } \\
\end{array}$ & \\
\hline 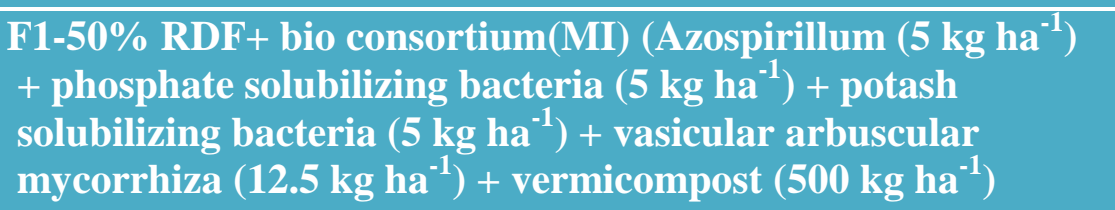 & \\
\hline $\begin{array}{l}\text { F2-75\% RDF+ bioconsortium(MI) (Azospirillum }\left(5 \mathrm{~kg} \mathrm{ha}^{-1}\right) \\
\text { +phosphate solubilizing bacteria }\left(5 \mathrm{~kg} \mathrm{ha}^{-1}\right)+\text { potash } \\
\text { solubilizing bacteria }\left(5 \mathrm{~kg} \mathrm{ha}^{-1}\right)+\text { vasicular arbuscular } \\
\text { mycorrhiza }\left(12.5 \mathrm{~kg} \mathrm{ha}^{-1}\right)+\text { vermicompost }\left(500 \mathrm{~kg} \mathrm{ha}^{-1}\right)\end{array}$ & \\
\hline F3- 100\% RDF & \\
\hline
\end{tabular}

Note: During summer, no fertilizer and herbicide was applied to the greengram crop.

Details of the herbicides used in the experiment

\begin{tabular}{|c|c|c|c|c|}
\hline Common name & Pendimethalin & Atrazine & Topramezone & Tembotrione \\
\hline Trade name & Stomp & Solaro & Tynzer & Laudis \\
\hline Formulation & $30 \% \mathrm{EC}$ & $50 \% \mathrm{WP}$ & $33.6 \% \mathrm{SC}$ & $42 \% \mathrm{SC}$ \\
\hline $\begin{array}{c}\text { Dose of herbicide (g } \\
\text { a.i. ha-1) }\end{array}$ & 750 & 1250 & 25 & 110 \\
\hline Time of application & Pre-emergence & $\begin{array}{c}\text { Pre- } \\
\text { emergence }\end{array}$ & $\begin{array}{l}\text { Post-emergence } \\
\text { (20 DAS) }\end{array}$ & $\begin{array}{c}\text { Post-emergence } \\
\text { (20 DAS) }\end{array}$ \\
\hline
\end{tabular}


Table.1 Total bacteria (CFU/g soil) count after harvest of maize as influenced by herbicides and microbial inoculants on rabi maizegreengram crop sequence

\begin{tabular}{|c|c|c|c|c|c|c|c|c|c|}
\hline & \multirow[t]{4}{*}{ Weed management practices (Main) } & & 2013-14 & & \multirow[t]{4}{*}{ Mean } & \multirow{2}{*}{\multicolumn{3}{|c|}{$\begin{array}{c}2014-15 \\
\text { Nutrient Levels (Sub) }\end{array}$}} & \multirow[t]{4}{*}{ Mean } \\
\hline & & \multicolumn{3}{|c|}{ Nutrient Levels (Sub) } & & & & & \\
\hline & & F1 & F2 & F3 & & F1 & F2 & F3 & \\
\hline & & $\begin{array}{c}\mathbf{5 0 \%} \\
\text { RDF+MI }\end{array}$ & $\begin{array}{c}75 \% \\
\text { RDF+MI }\end{array}$ & $\begin{array}{l}100 \% \\
\text { RDF }\end{array}$ & & $\begin{array}{l}\mathbf{5 0 \%} \\
\text { RDF+MI }\end{array}$ & $\begin{array}{c}75 \% \\
\text { RDF+MI }\end{array}$ & $\begin{array}{l}100 \% \\
\text { RDF }\end{array}$ & \\
\hline T1- & Weedy check & 6.21 & 6.41 & 6.17 & 6.26 & 6.14 & 6.39 & 5.97 & 6.17 \\
\hline T2- & Atrazine@1.25 kg ai ha ${ }^{-1}$ as pre-emergence & 6.30 & 6.63 & 6.22 & 6.38 & 6.29 & 6.60 & 6.04 & 6.31 \\
\hline T3- & Pendimethalin@0.75 kg ai ha ${ }^{-1}$ as pre-emergence & 6.18 & 6.60 & 6.09 & 6.29 & 6.18 & 6.81 & 6.14 & 6.38 \\
\hline T4- & $\begin{array}{l}\text { Topramezone@25 } \mathrm{g} \text { ai } \mathrm{ha}^{-1} \text { at } 20 \mathrm{DAS} \text { as post- } \\
\text { emergence }\end{array}$ & 6.39 & 6.89 & 6.17 & 6.48 & 6.32 & 6.91 & 6.20 & 6.48 \\
\hline T5- & $\begin{array}{l}\text { Tembotrione @ } 110 \mathrm{~g} \text { ai } \mathrm{ha}^{-1} \text { at } 20 \text { DAS as post- } \\
\text { emergence }\end{array}$ & 6.27 & 6.57 & 6.12 & 6.32 & 6.18 & 6.70 & 6.16 & 6.35 \\
\hline T6- & $\begin{array}{l}\text { Atrazine @ } 1.25 \mathrm{~kg} \text { ai ha } \mathrm{ha}^{-1} \text { as pre-emergence fb } \\
\text { Topramezone @ } 25 \mathrm{~g} \text { ai ha } \mathrm{ha}^{-1} \text { at } 20 \text { DAS as post- } \\
\text { emergence }\end{array}$ & 6.48 & 7.33 & 6.38 & 6.73 & 6.53 & 7.10 & 6.56 & 6.73 \\
\hline T7- & $\begin{array}{l}\text { Atrazine @ } 1.25 \mathrm{~kg} \text { ai } \mathrm{ha}^{-1} \text { as pre-emergence fb } \\
\text { Tembotrione @ } 110 \mathrm{~g} \mathrm{ai} \mathrm{ha} \text { at } 20 \text { DAS as post- } \\
\text { emergence }\end{array}$ & 6.29 & 6.77 & 6.10 & 6.39 & 6.15 & 6.67 & 6.12 & 6.32 \\
\hline T8- & 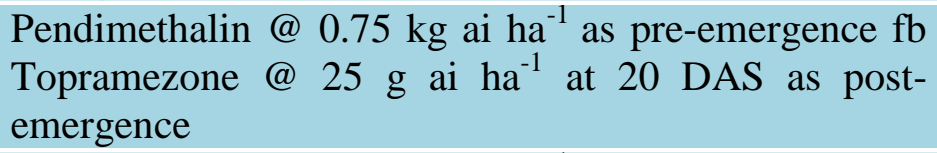 & 6.36 & 6.91 & 6.16 & 6.48 & 6.32 & 6.93 & 6.26 & 6.50 \\
\hline \multirow[t]{6}{*}{ T9- } & $\begin{array}{l}\text { Pendimethalin@ } 0.75 \mathrm{~kg} \text { ai ha }{ }^{-1} \text { as pre-emergence fb } \\
\text { Tembotrione @ } 110 \mathrm{~g} \mathrm{ai} \mathrm{ha} \mathrm{ha}^{-1} \text { at } 20 \text { DAS as post- } \\
\text { emergence }\end{array}$ & 6.17 & 6.78 & 6.10 & 6.35 & 6.20 & 6.77 & 6.15 & 6.37 \\
\hline & Mean & 6.29 & 6.77 & 6.17 & & 6.26 & 6.76 & 6.18 & \\
\hline & & SEm \pm & CD (0.05) & CV\% & & SEm \pm & CD (0.05) & CV\% & \\
\hline & Weed management practices (Main) & 0.039 & 0.117 & 20.1 & & 0.068 & 0.203 & 5.0 & \\
\hline & Nutrient levels (Sub) & 0.054 & 0.156 & 8.3 & & 0.062 & 0.117 & 3.1 & \\
\hline & Weed management practices X Nutrient levels & 0.068 & NS & & & 0.117 & NS & & \\
\hline
\end{tabular}


Table.2 Total actinomycetes (CFU/g of soil) count after harvest of maize as influenced by herbicides and microbial inoculants on rabi maize-greengram crop sequence

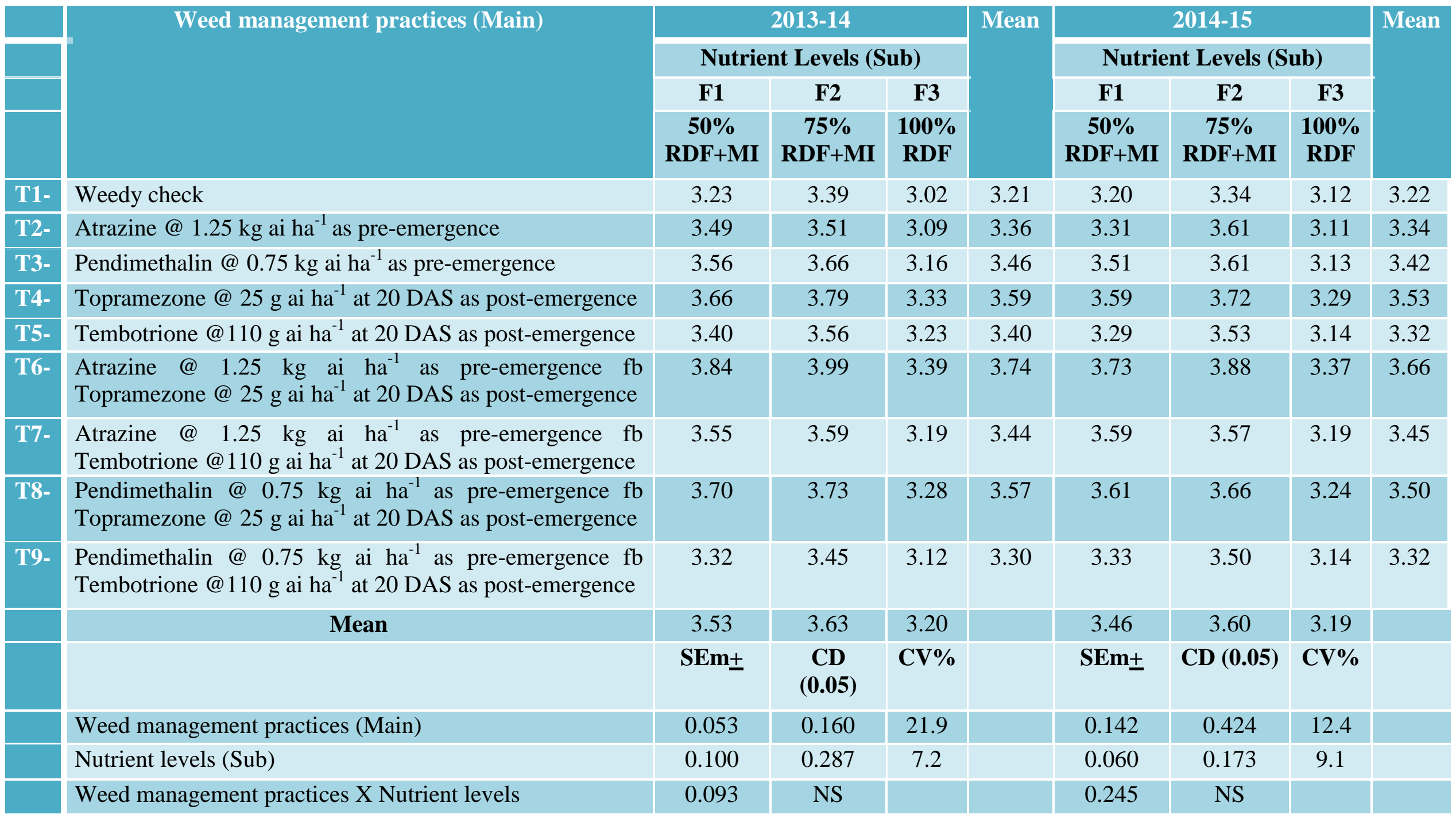


Table.3 Total fungi (CFU/g of Soil) count after harvest of maize as influenced by herbicides and microbial inoculants on rabi maizegreengram crop sequence

\begin{tabular}{|c|c|c|c|c|c|c|c|c|c|}
\hline & \multirow[t]{4}{*}{ Weed management practices (Main) } & \multirow{2}{*}{\multicolumn{3}{|c|}{$\begin{array}{c}\text { 2013-14 } \\
\text { Nutrient Levels (Sub) }\end{array}$}} & \multirow[t]{4}{*}{ Mean } & \multirow{2}{*}{\multicolumn{3}{|c|}{$\begin{array}{c}2014-15 \\
\text { Nutrient Levels (Sub) }\end{array}$}} & \multirow[t]{4}{*}{ Mean } \\
\hline & & & & & & & & & \\
\hline & & F1 & F2 & F3 & & F1 & F2 & F3 & \\
\hline & & $\begin{array}{c}\mathbf{5 0 \%} \\
\text { RDF+MI }\end{array}$ & $\begin{array}{c}75 \% \\
\text { RDF+MI }\end{array}$ & $\begin{array}{l}100 \% \\
\text { RDF }\end{array}$ & & $\begin{array}{c}\mathbf{5 0 \%} \\
\text { RDF+MI }\end{array}$ & $\begin{array}{c}75 \% \\
\text { RDF+MI }\end{array}$ & $\begin{array}{l}100 \% \\
\text { RDF }\end{array}$ & \\
\hline T1- & Weedy check & 4.26 & 4.37 & 3.94 & 4.19 & 4.05 & 4.17 & 3.83 & 4.01 \\
\hline T2- & Atrazine@1.25 kg ai ha ${ }^{-1}$ as pre-emergence & 4.36 & 4.65 & 4.34 & 4.45 & 4.14 & 4.27 & 4.11 & 4.17 \\
\hline T3- & Pendimethalin@0.75 kg ai ha ${ }^{-1}$ as pre-emergence & 4.47 & 4.52 & 4.12 & 4.37 & 4.26 & 4.30 & 4.17 & 4.25 \\
\hline T4- & Topramezone@25 g ai ha ${ }^{-1}$ at 20 DAS as post-emergence & 4.39 & 4.54 & 4.29 & 4.41 & 4.28 & 4.46 & 4.19 & 4.31 \\
\hline T5- & Tembotrione@110 g ai ha ${ }^{-1}$ at 20 DAS as post-emergence & 4.37 & 4.38 & 4.30 & 4.35 & 4.33 & 4.39 & 4.30 & 4.34 \\
\hline T6- & $\begin{array}{l}\text { Atrazine @ } 1.25 \mathrm{~kg} \text { ai } \mathrm{ha}^{-1} \text { as pre-emergence } \\
\text { fbTopramezone @ } 25 \mathrm{~g} \text { ai } \mathrm{ha}^{-1} \text { at } 20 \text { DAS as post- } \\
\text { emergence }\end{array}$ & 4.62 & 4.85 & 4.34 & 4.60 & 4.95 & 5.11 & 4.57 & 4.88 \\
\hline T7- & $\begin{array}{l}\text { Atrazine @ } 1.25 \quad \mathrm{~kg} \text { ai } \mathrm{ha}^{-1} \text { as } \\
\text { fbTembotrione } \\
\text { emergence }\end{array}$ & 4.49 & 4.63 & 4.30 & 4.47 & 4.40 & 4.47 & 4.39 & 4.42 \\
\hline T8- & 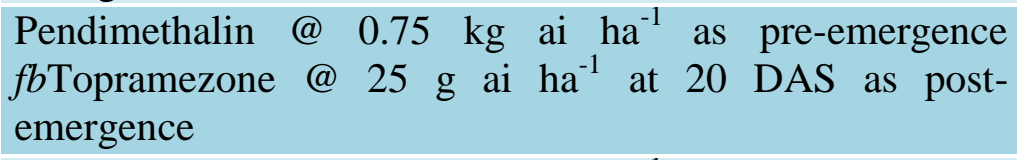 & 4.55 & 4.59 & 4.30 & 4.48 & 4.51 & 4.62 & 4.34 & 4.49 \\
\hline T9- & $\begin{array}{l}\text { Pendimethalin @ } 0.75 \mathrm{~kg} \text { ai ha } \mathrm{ha}^{-1} \text { as pre-emergence } \\
\text { fbTembotrione @ } 110 \mathrm{~g} \text { ai ha } \mathrm{ha}^{-1} \text { at } 20 \text { DAS as post- } \\
\text { emergence }\end{array}$ & 4.29 & 4.44 & 4.17 & 4.30 & 4.33 & 4.45 & 4.27 & 4.35 \\
\hline & Mean & 4.42 & 4.55 & 4.23 & & 4.36 & 4.47 & 4.24 & \\
\hline & & SEm \pm & CD (0.05) & CV\% & & SEm \pm & CD (0.05) & CV\% & \\
\hline & Weed management practices (Main) & 0.032 & 0.095 & 9.9 & & 0.057 & 0.172 & 3.9 & \\
\hline & Nutrient levels (Sub) & 0.061 & 0.176 & 6.3 & & 0.031 & 0.090 & 3.7 & \\
\hline & Weed management practices X Nutrient levels & 0.055 & NS & & & 0.100 & NS & & \\
\hline
\end{tabular}


Total fungi (CFU/g of Soil) count after harvest of maize and before sowing of greengram

Weed management and nutrient management practices significantly influenced the total fungi count after harvest of maize and before the sowing of greengram during the both the years of investigation (Table 3).

Highest total fungi count was recorded in atrazine@1.25 kg ai ha ${ }^{-1}$ as pre-emergence fbtopramezone@25 g ai ha ${ }^{-1}$ at 20 DAS as post-emergence (T6) which was significantly superior over all other weed management practices during both the years of study. The lowest total fungi count was recorded in weedy check (T1).

With regard to total fungi count weed management practices differ among themselves. This might be due to the utilization of herbicidal molecules as inorganic nutrients for the fungal multiplication in the soil. These findings are in close comparable with the findings of Jaya Malhotra et al., (2015). With regard to nutrient management practices highest total fungi count was recorded in F2 $(75 \%$ $\mathrm{RDF}+\mathrm{MI})$ which was on par with $\mathrm{F} 1(50 \%$ $\mathrm{RDF}+\mathrm{MI})$ and these treatments were significantly superior over F3 (100\% RDF) during both the years of investigation.

It might be due to the action of microbial consortium which was applied in F2 (75\% $\mathrm{RDF}+\mathrm{MI})$ and $\mathrm{F} 1$ (50\% RDF+MI) treatments in combination reduced doses of chemical fertilizer caused a synergistic influence in enhancing total fungal counts in comparison to the F3 (100\% RDF) application.

Interaction effect of weed management and nutrient management practices was nonsignificant on total bacteria, actinomyctes and fungi count after harvest of maize and before sowing of greengram during the both the years of study.

\section{References}

Allen, O.N. 1957. Experiments in Soil Bacteriology. $3^{\text {rd }}$ Edition, Burgees Publ. Co. Minneapolis, Minnesota.

Hawaldar Shantveerayya and Agasimani, C. A. 2012. Effect of herbicides on weed control and productivity of maize (Zea mays L.). Karnataka Journal of Agricultural Sciences. 25 (1): 137-139.

Hayat, R, Ali, S., Amara, V., Khalid, R and Ahmed, I. 2010. Soil beneficial bacteria and their role in plant growth promotion: a review. Annals of Microbiology. 60(4): 579-598.

Jaya Malhotra. Aparna, K. AnkitaDua. NaseerSangwan. Trimurtulu, N. Rao, D. L. N. and Rup Lal 2015 Microbial and genetic ecology of tropical Vertisols under intensive chemical farming. Environment Monit. Assessment. 187: 4081

Shannon, D., Raverkar, K.P and Sa, J.C.M. 2002. A comparative study of the microbiology of the soils managed under organic and conventional regimes. Soil Use and Management, 18: 274-283.

Simpson, R.J., Oberson, A., Culvenor, R.A., Ryan, M.H., Veneklass, E.J and Lambers, H. 2011. Strategies and agronomic interventions to improve the phosphorous use efficiency of farming systems. Plant Soil. 342 (1-2): 89-120

Trimutulu, N. Ashok, S. Latha, M. and Rao, A.S. 2015. Influence of reemergence herbicides on the soil microflora during the crop growth of blackgram, Vigna mungo L. International Journal of Current Microbiology and Applied sciences, 4(6): 539-546.

Zhang, N.N., Sun, Y.M., Li, L., Wang, E.T., Chen, W.X and Yuan, H. L. 2010. 
Effects of intercropping and Rhizobium inoculation on yield and rhizosphere bacterial community of Faba (Viciafaba
L). Biology and Fertility of Soils. 46: 625-639.

\section{How to cite this article:}

Subba Ramireddy, A., A.S. Rao, G. Subba Rao, T.C.M. Naidu, A. Lalitha Kumari and Trimurthulu, N. 2018. Effect of Different Herbicidal Treatments on Soil Microflora in Maize Greengram Crop Sequence. Int.J.Curr.Microbiol.App.Sci. 7(11): 1230-1238. doi: https://doi.org/10.20546/ijcmas.2018.711.143 